\title{
COLLABORATIVE GOVERNANCE IN THE MANAGEMENT OF PLASTIC WASTE BANKS IN PASURUAN REGENCY EAST JAVA PROVINCE
}

\author{
Dr. Selfi Budi Helpiastuti, S.Sos, M.Si; Siti Jahro, S.Sos \\ Public Administration Study Program, Faculty of Social and Political Sciences, \\ University of Jember \\ selfibudihelpiastuti@unej.ac.id
}

\begin{abstract}
This study describes collaborative governance in the management of plastic waste bank in Pasuruan Regency. The problem of plastic waste experienced by Pasuruan Regency regarding the ineffectiveness of plastic waste management has led to Government efforts to overcome it, one of which is through a plastic waste bank. The emergence of plastic waste banks in Pasuruan Regency began with the participation of the community. This study uses a qualitative approach, a type of descriptive research and uses two types of data, namely primary data and secondary data. Data obtained through in-depth interviews, observation, and document analysis. Determination of research informants was done purposively. The validity of the data uses triangulation and analysis techniques using interactive models. The results of the study show that collaborative governance in the management of plastic waste banks has been carried out through four stages, namely assessment, initiation, deliberation, and implementation. The process of collaborative governance begins with the process of assessment or identification, carrying out plastic waste management involving several stakeholders. Next is the initiation process, conducting deliberations which were attended by stakeholders. Then the stages of deliberation through deliberation and dialogue to reach agreement between stakeholders in collaborating and the last stages of implementation carried out by all stakeholders in accordance with the assigned division of tasks. Collaboration in the management of plastic waste banks is still semiformal, which is only based on the commitment of the stakeholders involved.
\end{abstract}

Keywords: collaborative governance, management of plastic waste banks

\section{INTRODUCTION}

Plastic waste management is in Kiduldalem Village, Jogosari Village, and Pleret Village, Pasuruan Regency. Preliminary observations illustrate that Pasuruan Regency is currently experiencing plastic waste problems which only have one Final Disposal Site, namely a landfill in Kenep and experiencing excess capacity. The plastic waste generation at the Kenep Final Disposal which has an area of approximately $2250 \mathrm{~m} 2$ reaches $4707.6 \mathrm{~m} 3$, equivalent to 940 tons of plastic waste produced per day. While the capacity of plastic waste that can enter the Kenep Final Disposal Site is only about 1,200 $\mathrm{m} 3$, equivalent to 240 tons of plastic waste (surabaya.tribunnews.com). In addition, the management of plastic waste in Pasuruan Regency has not been effective and plastic waste management activities involving the community have not been optimal. This is due to the provision of Temporary Disposal facilities in the Reduce, Reuse, and Recycle models that will be synergized with plastic waste banks that are still in process and 
have not run optimally. The management of plastic waste through a plastic waste bank was launched by Pasuruan Regent Mr. Irshad Yusuf since 2014 known as One Village One Bank Waste Plastic. Currently in Pasuruan Regency there are 41 units of plastic waste banks spread across 27 villages and sub-districts. This study focused its discussion on the Plastic Waste Bank located in Kiduldalem Village, Bangil District, Jogosari Village, Pandaan District, and Pleret Village, Pohjentrek District.

Kiduldalem Village was chosen as the region that first established a plastic waste bank in Pasuruan Regency and Kiduldalem Village has the largest number of plastic waste banks in Pasuruan, which are as many as ten plastic waste banks, although currently only seven plastic waste banks are active. The interview with Mr. Bambang EP as the Head of Kiduldalem Village for the period of 2011-2017 stated that the Kiduldalem Village received a slum predicate from the Health Office. In addition, the Kiduldalem Village is a strategic area as a trading center, as evidenced by the existence of markets and two plazas, the western plaza and the eastern plaza. Then many small entrepreneurs and various kinds of Micro Small Businesses were found such as cake entrepreneurs, embroidery craftsmen, and silver craftsmen. This high economic potential has an impact, namely high production of plastic waste and has not been well managed. Mr. Bambang EP as the Head of Kiduldalem Urban Village for the period of 2011-2017 has an initiative to handle one of them by managing plastic waste through a plastic waste bank by involving the community group of Kiduldalem Village, the Team for the Promotion of Family Welfare Development. The plastic waste bank in Kiduldalem Village is often chosen as the objective in the assessment of Adipura in Pasuruan Regency and is able to contribute added value in the assessment of Adipura. And proven by several achievements in the field of environment that got Bangil City like the Adipura Cup in 2014, then in 2015 received a plaque, and in 2016 the City of Bangil won the Adipura Cup again and was able to maintain in 2017 (news.detik.com).

Then for the selection of Jogosari Village especially Rajawali Environment because it is one of the region in Pasuruan Regency, west region far from the capital city of Pasuruan which also has problems related to environmental cleanliness, namely the famous slum environment and frequent delays in cleaning plastic waste by janitors. Based on the results of the interview above, it can be understood that the Rajawali environment in Jogosari Village has a majority of the population who work as traders, so that the resulting plastic waste is also increasing and if there is a delay in the collection it will cause a problem of plastic waste accumulation. The existence of these problems then came the idea of a young RT 03 RW 06 Gang Rajawali Jogosari Village to establish a plastic waste bank. This environmental care movement has been carried out since 2016, but the establishment of Rajawali Environmental Care Plastic Waste Bank was officially on February 7, 2017. Since the establishment of this plastic waste bank was able to produce changes in RT 03 RW 06 Gang Rajawali Jogosari Village, as evidenced by the Mural in along the road, plastic waste crafts are installed in the riverbank area, and rivers that are free of plastic waste. Although it is relatively new and is still on the RT scale, "Rajawali Peduli Lingkungan" Waste Bank. Bank has its own 
fleet that is purchased through self-help from the community. The fleet is used to transport plastic waste residents to a landfill that is not far from Jogosari Village and also to sell plastic waste in a plastic waste bank warehouse to be sold to plastic waste collectors. In addition, the "Rajawali Peduli Lingkungan" Plastic Waste Bank has also carried out several activities such as plastic waste raid conducted in rivers along with several parties including the Jogosari Village Government, Pasuruan Regency Environmental Agency, Pasuruan Regency Environmental Care Communication Forum, and the environmental community. In addition, the management of the Plastic Waste Bank, "Rajawali Peduli Lingkungan", also actively submitted proposals for assistance to several companies and it was proven by the existence of plastic waste tanks placed along the road.

While the election of Pleret Village was because it had been awarded as the Regent's Choice Favorite Village on the "Bangkit Desaku" event held in 2017. This was because Pleret Village had a program similar to the Pasuruan Regency Government, namely developing "Satu Desa Satu Bank Limbah" with the hope can be a model for other villages in Pasuruan Regency (www.radarmalang.id). The establishment of the "Kampung Limo" plastic waste bank in Pleret Village was due to a lack of public awareness about the environment as well as plastic waste stacks which were mounting on the banks of the river in the range of 2013-2014. "Kampung Limo" Plastic Waste Bank was established in 2014 and currently has 90 customers. Another interesting thing from Pleret Village plastic waste bank is that it has better facilities and infrastructure than other plastic waste banks with plastic waste bank buildings originating from community self-help for land acquisition and the construction of village aids through the Village Fund Allocation in 2016 amounting to 66 million rupiah (tribunusantara.com)

Based on the interesting things outlined above, the researcher will describe how the collaboration between stakeholders in the management of plastic waste in Kiduldalem Village, Jogosari Village, and Pleret Village, Pasuruan Regency.

\section{LITERATURE REVIEW}

\section{Collaborative Governance}

Morse and Stephens (2012: 566) argue that "collaborative is added as a modifier to governance to emphasize the nature of the processes involved in collective action". There are four stages which are the collaboration phase in governance according to Morse and Stephens (2012: 567-569), namely stages: (a) assessment is how the initial conditions greatly influence success in collaboration between stakeholders, this stage is to identify whether collaboration is needed and possible to be implemented or not; (b) initiation is to build commitment between stakeholders to work together which includes the identification of conveners and the role of sponsors that might be human resources and funding sources, activities of stakeholder meetings to build work groups in the process design; (c) deliberation is the activity of establishing ground rules or establishing basic rules, then holding deliberations and dialogues to reach collaborative 
agreements or cooperation agreements; (d) implementation is a stage that can determine whether collaboration can continue or must be terminated when the collaboration process occurs but problems that allow collaboration cannot continue.

Management of plastic waste banks

According to George R. Terry (in Saifuddin, 2014: 53-54), management is a distinctive process, which consists of actions of planning, organizing, mobilizing, and supervising carried out to determine and achieve the targets set through utilization of human resources and other sources. Whereas related to plastic waste banks, According to Utami (2013: 2) plastic waste banks are a collective system of dry plastic waste management that encourages people to take an active role in it. This system will accommodate, sort and distribute economically valuable plastic waste to the market so that people get economic benefits from saving plastic waste. The working method of a plastic waste bank is to collect dry or non-organic plastic waste for sale to designated collectors (Munasya, 2016). Based on various descriptions above, it can be seen that the management of plastic waste banks is an effort to manage 3R-based plastic waste (Reduce, Reuse, and Recycle) through plastic waste banks by empowering other parties to achieve their goals, namely sorting, handling and reducing plastic waste.

\section{RESEARCH METHODS}

The approach used in this study is a qualitative approach with a type of descriptive research. To get research data using several data collection techniques, namely: in-depth interviews, direct observation, and document analysis. Next to test the validity of the data, researchers used triangulation. Then the determination of the informants in this study used a purposive technique. There were 20 informants, consisting of staff from the Environmental Office of Pasuruan Regency, Head of Kiduldalem Village, Head of Jogosari Village, Head of Pleret Village, Chair of the Environmental Care Communication Forum, BISS Plastic Waste Bank Manager, Plastic Waste Bank Manager Rajawali Care for Environment, Kampung Limo Plastic Waste Bank Manager, community, and collectors. The analytical method used is an interactive analysis model by Miles and Huberman, namely data collection, data reduction, data presentation, and conclusion drawing.

\section{RESULTS AND DISCUSSION}

In the management of plastic waste in Kiduldalem Village, Jogosari Village, and Pleret Village, Pasuruan Regency there is a pattern of cooperation between stakeholders in the form of collaborative governance. The stages passed in collaboration with the management of the Plastic Waste Bank include the following stages.

\section{A. Stage of Assessment}

The assessment of the collaboration in the management of plastic waste banks in Pasuruan Regency has been carried out based on the initial conditions of each environment before the existence of plastic waste banks, such as in the Kiduldalem 
Village, Pleret Village, and Jogosari Village. Before the existence of a plastic waste bank, the three locations had problems related to public awareness of the environment. This has led to the initiative to form a plastic waste bank. The initiative to form a plastic waste bank based on the results of research at three locations found that at the BISS Plastic Waste Bank Kiduldalem Village came from the initiative of Kiduldalem Urban Village Head, Kampung Limo Plastic Waste Bank came from a female leader who was the PKK RW team leader, and at the Waste Bank Rajawali Plastics Cares for the Environment comes from the youth initiative RT. 03 RW.06 environment Rajawali Jogosari Village.

The existence of these initiatives is necessary to collaborate with various parties. As has been done at the BISS Plastic Waste Bank, the village head involved women leaders who were members of the PKK Driving Team and community leaders. Furthermore, at the Kampung Limo Plastic Waste Bank, the Head of the RW 5 PKK Team involved community leaders consisting of the Chairperson of RW.5, RT.1, RT.2, RT.3, RT.4, and RW.5 in managing the village plastic waste bank limo, besides that it also involved the Pleret Village Government. And at Rajawali Peduli Lingkungan plastic waste bank, youth RT. 03 RW.06 environment of Rajawali also involves the region government, community leaders, and the Environmental Care Communication Forum of Pasuruan Regency.

Every plastic waste bank located in Pasuruan Regency also involves the Pasuruan Regency Environmental Agency. However, the Pasuruan Regency Environmental Agency did not conduct an assessment in the field, but normatively the Environmental Agency understood every problem from the plastic waste bank - a plastic waste bank located in Pasuruan Regency.

Stakeholders are involved in management collaboration at each plastic waste bank. Stakeholders who have the initiative to form a plastic waste bank are actors who act as conveners where they are key actors as organizers who invite to meet or hold meetings with other stakeholders who are involved in collaborating with the management of plastic waste banks.

Some of the above analyzes can be drawn out that the stages of identification or assessment on the collaboration management of waste plastic banks in Pasuruan Regency have been carried out, this is evidenced by the answer to the four questions at the stage of assessment collaborative governance.

\section{B. Initiation Stage}

The Initiation process in collaboration with the management of waste plastic banks in Pasuruan Regency was conducted to frame the problems that occur in each environment before the existence of a plastic waste bank. As in the BISS plastic waste bank, the collaboration between the management of plastic waste banks was carried out to frame the problems experienced by Kiduldalem Village, which is related to the predicament of city slums so that the region of government took the initiative to collaborate with female leaders and community leaders to overcome these problems. . Then the limo plastic waste bank was carried out due to a lack of public awareness of 
the environment so that one of the female figures or the head of the RW PKK Team took the initiative to form a plastic waste bank and invited other stakeholders to collaborate. And at the Environmental Care Rajawali plastic waste bank, it was also conducted to overcome environmental problems RT-03 RW.06 Gang Rajawali, Jogosari Village, which is famous for its slums and community unrest related to the problem of delays in plastic waste collection carried out by janitors. This led to the initiative of the RT.03 youth RW.06 gang Rajawali to invite other stakeholders to get involved in overcoming the problem so that a plastic waste bank emerged. How to engage stakeholders in the initiation stage is carried out by holding a meeting attended by the stakeholders involved.

In addition, at the initiation stage the collaboration in managing the plastic waste bank also involves human resources and funding sources. At the BISS plastic waste bank, the human resources involved include the Environmental Agency which is currently the Department of Environment of Pasuruan Regency. How to involve it by inviting the Department of Environment of Pasuruan Regency as a resource person in the first meeting between the Village Government, community leaders and female leaders. Besides that, it also involved one of the community leaders who worked as collectors, namely the head of RW.7 even though the collaboration had only been running for several years because he had moved. Regarding funding sources, the Kiduldalem village government has also submitted a proposal to the East Java Provincial Government for the submission of assistance and is proven by the assistance of scales for the BISS plastic waste bank. In addition to submitting proposals to the Province there were also funding sources from the Indolakto company in 2014. This was evidenced by the acknowledgment of the Chair of the Joint Waste Plastic Bank "Bersinar" Kiduldalem who stated that he had received funding from the Indolakto company.

Then at Kampung Limo plastic waste bank also involved human resources, namely the community of RW.05. Pleret Village who was involved in the meeting for the construction of a plastic waste bank building and the community of RW 05 Pleret Village was involved in the construction of a plastic waste bank building. In addition there are funding sources such as community self-help, village funds and assistance from the Department of Environment in Pasuruan in the form of scales. Whereas at Rajawali Peduli Lingkungan plastic waste bank, the source of funds is obtained from surrounding companies in the form of physical facilities such as plastic waste tubs, community self-help which are used for fleet purchases through plastic waste charity activities, submission of vehicle assistance proposals to the Pasuruan Regency Environmental Agency.

At the initiation stage of the Department of Environment, one of the resources of each waste plastic bank, namely the Department of Environment of Pasuruan Regency facilitates existing plastic waste banks by conducting socialization, guidance, and assistance in the form of infrastructure. Some of the above analyzes can be drawn out 
that the initiation stage of collaborative governance in the management of plastic waste banks in Pasuruan Regency has been well implemented.

\section{Deliberative stage}

The deliberative process in collaboration with the management of plastic waste banks in Pasuruan Regency is carried out through deliberation and dialogue with stakeholders involved in each plastic waste bank. During the deliberations, a commitment was made by the stakeholders involved to work together. Like at the BISS plastic waste bank, deliberations have been held between stakeholders on February 22, 2013, at the Kampung Limo plastic waste bank, the meeting was held on April 3, 2014, and at the Rajawali Peduli Lingkungan plastic waste bank the meeting was held on February 72017.

During the deliberations and dialogues an agreement was reached to collaborate. However, related to the basic rules in the collaboration management of plastic waste banks, the deliberations of stakeholders involved in collaborative management of plastic waste banks did not discuss the basic rules that became a reference in collaborating. Collaboration on managing plastic waste banks is based solely on the commitment between stakeholders to support each other and work together in the management of plastic waste banks. This researchers found in every plastic waste bank. So that based on the analysis of the deliberation stage, there are no basic rules in the collaboration of the management of plastic waste banks. Some of these analyzes, it can be drawn out that the deliberative stages in the collaboration management of plastic waste banks are already underway, but not optimal, because in collaboration with the management of plastic waste banks, there are no written basic rules so collaboration is only based on commitment among stakeholders.

D. Implementation Phase

In the implementation phase in the collaboration of managing waste plastic banks in Pasuruan Regency each plastic waste bank has a division of tasks. The division of tasks is in accordance with the results of the mutual agreement of each stakeholder and has been determined by the Village or Village Government through a decree. As with the BISS plastic waste bank, the division of tasks has been determined through a Decree of the Head of the Kiduldalem Village in Bangil District, Pasuruan Regency No: 05 of 2013 concerning Management of Plastic Waste / Plastic Waste Banks. Furthermore, in Kampung Limo plastic waste bank, the division of tasks among stakeholders has also been determined through a Decree of the Head of Pleret Village, Pohjentrek District, Pasuruan Regency No: 141/15 / 424.217 .03 / 2014 concerning Plastic Waste Management / Plastic Waste Banks. And the division of tasks at the Rajawali Environmental Care plastic waste bank was determined through a Decree of the Head of the Jogosari Urban Village, Pandaan District, Pasuruan Regency Number: 521/03 / 424.311.1.01 / 2017 concerning the Establishment of Rajawali Plastic Waste Bank Care for the RT. 03 RW. 06 Gang Rajawali, Jogosari Village, Pandaan District. In the decree it was explained related to the management structure accompanied by the duties and roles of each stakeholder. 
Furthermore, related to how to build constituent support or how to expand support in the management of plastic waste banks in Pasuruan Regency is carried out by means of disseminating information to the community regarding plastic waste banks and appealing to join to become customers of plastic waste banks. For example, the management of the BISS plastic waste bank, Kampung Limo plastic waste bank, and Rajawali Plastic Waste Bank Care for the Environment.

In addition to building constituent support through socialization of citizens, there are several plastic waste banks that expand support by collaborating with private parties or companies. Like the BISS plastic waste bank that expanded support with the Indolakto Company in 2014 through a network owned by the Kiduldalem Village for the period 2011-2017. In addition, the plastic waste bank Rajawali also built support from the Aqua Company. Meanwhile Kampung Limo plastic waste bank is still in the planning stage to expand support with the private sector or the company.

Related to monitoring and evaluation of the results of agreements between stakeholders have been carried out by each plastic waste bank through coordination, guidance and evaluation meetings. Although based on the results of interviews conducted in the field, results were obtained that monitoring and evaluation activities were carried out informally and unscheduled. Evaluation activities are carried out to identify and overcome the constraints that exist in the management of plastic waste banks, such as Kampung Limo plastic waste bank and Rajawali Plastic Waste Bank Caring for the Environment. However, at the BISS plastic waste bank, based on the results of the interview, it was known that the evaluation on the management collaboration of the BISS plastic waste bank had been conducted every three months by the Kelurahan government along with the management of the plastic waste bank, even though the evaluation activities had not yet proceeded due to the replacement of the Village Government.

Based on the description above, the implementation stages have been implemented in collaboration with the management of plastic waste banks in Pasuruan Kabuapaten. The stages of implementation have also been running optimally.

\section{CONCLUSIONS AND RECOMMENDATIONS}

Based on the results of research on collaboration in the management of waste plastic banks in Pasuruan Regency conducted at the BISS Plastic Waste Bank, Kampung Limo Plastic Waste Bank, and Rajawali Plastic Waste Environmental Care Bank, the following can be concluded.

1. The process of collaborative governance begins with the process of assessing or identifying that there are environmental problems related to plastic waste so that a solution to problem solving is needed by managing plastic waste by involving several stakeholders. After that, it was continued with the initiation process by conducting deliberations which were attended by stakeholders. Then proceed with the stages of deliberation through deliberation and dialogue to reach an agreement between stakeholders to work together and proceed with the stages of 
implementation carried out by all stakeholders in accordance with the assigned division of tasks.

2. The role of stakeholders after a collaborative agreement in the management of the BISS plastic waste bank, Rajawali Plastic Waste Bank Care for the Environment, and Kampung Limo plastic waste bank as follows.

a) PKK Driving Team Group in RW 06 Kiduldalem Village and RW 05 Pleret Village and youth in RT 03 RW 06 Rajawali Gang Jogosari Village act as managers who run the operations of a plastic waste bank.

b) Village or Urban Governments act as protectors and facilitators in the management of plastic waste banks.

c) Community leaders as supporters in the activities of plastic waste banks and join in inviting the public to be involved in the activities of plastic waste banks.

d) The Environmental Office of Pasuruan Regency acts as a facilitator in the implementation of plastic waste banks.

e) The Environmental Care Communication Forum (FKPL) of Pasuruan Regency acts as a facilitator who accompanies the management of Rajawali plastic waste bank to care about the environment technically.

f) Collectors act as a place to deposit plastic waste produced from customers for sale.

\section{SUGGESTION}

Based on the results of the study, the researcher presented several suggestions as follows.

1. Plastic waste banks should cooperate with various parties such as permanent collectors

2. for those who do not have permanent collectors so that plastic waste can be routinely deposited and the market can sell the results of recycled handicrafts so that they can increase the income of the community.

3. There is a need for intensive involvement of the Environmental Agency on the management of plastic waste banks considering that plastic waste banks are one alternative that can help overcome environmental problems and by having a plastic waste bank can minimize the amount of plastic waste entering the landfill.

\section{DAFTAR PUSTAKA}

\section{Buku:}

Saifuddin. 2014. Pengelolaan Pembelajaran Teoretis dan Praktis.Yogyakarta: Depublish.

Utami, Eka. 2013. Buku Panduan Sistem Bank Limbah plastik \& 10 Kisah Sukses. Jakarta: Yayasan Unilever Indonesia.

Jurnal: 
Morse, R. S \& Stephens, J. B. 2012. Teaching Collaborative Governance: Phases, Competencies, and CaseBased Learning. Journal of Public Affairs Education, 18(3), 565-584

\section{Internet:}

Arifin, M. 2017. Kabupaten Pasuruan Pertahankan Piala Adipura untuk Kota Bangil. https://news.detik.com/berita-jawa-timur/d3577566/kabupaten-pasuruanpertahankan-pialaadipura-untuk-kota-bangil. 30 September 2018.

Munasya. 2016. Begini Cara Mengelola Bank Limbah plastik.

http://munasya.com/\%E2\%80\%8Bbegini-caramengelola-bank-limbah plastik/. 22 Januari 2018.

Prabowo. 2016. Yuk, Mengenal Lebih Dekat Bank Limbah plastik 'Kampoeng Limo' Desa Pleret Pohjentrek. https://tribunusantara.com/2017/02/16/yukmengenal-lebih-dekat-bank-sampa.html. 3 Oktober 2018

Anonim. 2017. Ini dia 17 Desa di Kabupaten Pasuruan yang Meraih Penghargaan Bangkit Desaku Sinergi Jawa Pos. http:/ / www.radarmalang.id/ini-dia-17desa-di-pasuruan-yang-meraih-penghargaanbangkit-desaku-sinergi-jawa-pos/. 3 Oktober 2018 